\title{
Assessing the hydrological suitability of floodplains for species- rich meadow restoration: a case study of the Thames floodplain, UK
}

\author{
A.J. Durane1 ${ }^{1,2}$, M.C. Acreman ${ }^{1,2}$, C.J. Stratford ${ }^{1}$, J.R. Thompson ${ }^{2}$ and D.J. Mould ${ }^{1,2}$ \\ ${ }^{1}$ Centre for Ecology and Hydrology, Maclean Building, Crowmarsh Gifford, Wallingford, Oxfordshire, OX10 8BB, UK \\ ${ }^{2}$ Wetland Research Unit, Department of Geography, UCL, 26 Bedford Way, London, WC1H OAP, UK
}

Email for corresponding author: man@ceh.ac.uk

\begin{abstract}
The physical and chemical environment of a floodplain needs to be assessed to define conservation targets for restoring it to species-rich meadows from agricultural land. A straightforward technique, widely applicable by site managers for assessing the suitability of the hydrological and hydro-chemical regime of a floodplain for wet grassland restoration, has been tested by examining the feasibility of restoring plants characteristic of NVC MG4 and MG8 communities to the Castle Meadows, Wallingford (Oxfordshire, UK). Hydro-chemical suitability has been assessed by comparing phosphorus concentrations with species-rich meadows nearby. The flooding regime was estimated based on a rating curve and a digital elevation model and groundwater levels were measured monthly in dipwells and piezometers. The hydrological regime was then compared with published reference guidelines for communities of conservation interest. For the Castle Meadows, the maximum duration of flood events in autumn and winter exceeded MG4 and MG8 species requirements across half of the site, while the depth of the groundwater table in summer exceeded species requirements in the other half. It was shown that, depending on topography, MG5 or MG13 may be more realistic vegetation targets.
\end{abstract}

Keywords: floodplain meadow, restoration, conservation target, flooding regime, hydrology, Thames

\section{Introduction}

Lowland wet grasslands and meadows have undergone a severe decline throughout Europe during the last century. For example, of the 1.2 million ha of historical lowland wet grasslands in England and Wales, only 220000 ha remain, with less than 20000 ha being unimproved grassland of high conservation value (Manchester et al., 1999). This dramatic decline has largely been the result of modifications to farming practices (e.g. intensification of the agricultural management of traditional water meadows through ploughing, seeding of improved species, application of fertilisers and drainage) and changes to river regime, particularly flooding patterns, due to embankment construction for flood protection and water abstraction.

Lowland wet meadows are now recognised as a habitat worthy of conservation at both national and European scales (Acreman and José, 2000). For instance, the UK Biodiversity
Action Plan has a target of restoring 500 ha of this habitat by 2010 (UK Biodiversity Steering Group, 1995). Attempts have been made to restore species-rich wet meadows on improved agricultural land, either through agroenvironmental schemes or following purchase by conservation organisations (Manchester et al., 1998a, b; 1999; McDonald, 2001). Reinstating traditional extensive management on improved grasslands may well have led to positive changes in species-richness and botanical composition, but not to shifts in vegetation community types (Walker et al., 2004).

The crucial element for success in restoration is the appropriate physical conditions at the site. The water regime is the most important physical factor influencing vegetation in floodplain meadows (Gowing and Youngs, 1997; Grevilliot et al., 1998), acting through both drought and aeration stresses (Gowing and Spoor, 1998). It is, therefore, 
essential to evaluate the water regime of a site before establishing restoration targets (Gilbert et al., 2003). Assessment of the hydrological regime is complex and there is a pressing need for a simple and cost-effective approach that can be applied by conservation organisations with limited hydrological expertise.

Artificially high nutrient concentrations in the soil are an important obstacle to restoration of species-rich communities (Marrs, 1993). This is particularly true of phosphorus (Oomes et al., 1996). In a survey of grasslands across Europe, Janssens et al. (1998) only found species-rich sites containing less than $50 \mathrm{mg} \mathrm{kg}^{-1}$ of extractable (acetate + EDTA) phosphorus. Maximum species richness was achieved at $4 \mathrm{mg} \mathrm{kg}^{-1}$ and a target value of $5-10 \mathrm{mg} \mathrm{kg}^{-1}$ of extractable phosphorus has been suggested for restoring species-rich meadows (Gough and Marrs, 1990b; Snow et al. , 1997). In a large-scale fertiliser experiment, Tallowin et al. (1998) showed that phosphorus was more influential than either nitrogen or potassium in determining botanical composition in wet meadows. Because of the large and widespread use of fertiliser, levels of extractable phosphorus are much higher in arable or pasture soils than in seminatural grasslands (Gough and Marrs, 1990a), thus limiting restoration potential.

Other obstacles to restoration include the very low species recruitment and reassembly rates of species-rich grasslands (Bischoff, 2002; Donath et al., 2003) due to insufficient soil seed banks, dispersal and seedling implantation. For example, the lack of seeds of desirable species can be a key factor limiting the assembly of diverse grassland communities (Pywell et al., 2002) so that artificial introduction of propagules is often needed (Manchester $e t$ al., 1999).

This paper presents a straightforward technique that can be applied widely to determine whether the physical and chemical environment of the site is appropriate for the restoration of wet grassland. The technique focuses on the hydrological conditions and soil water nutrient status as key characteristics controlling site suitability of wet grasslands; it employs simple field observations and does not need detailed laboratory analysis. The technique is described through a case study that assesses the feasibility of restoring wet grassland to the Thames floodplain at Wallingford (Oxfordshire, UK).

\section{The site}

The Thames Valley is the major floodplain in southern England. Wet meadows were once numerous, but many have been degraded by agricultural practices or embankments constructed for flood protection. Castle Meadows are an example of such a site. They lie within 16.6 ha of Victorian parkland on and around a feudal motte in the centre of Wallingford, South Oxfordshire (grid reference SU612899). The two lowest fields, King's Meadow and Queen's Arbour, extend across the Thames floodplain from the river to a higher terrace upon which the castle was built.

Around Wallingford, the floodplain lies on a broad valley in-filled with Pleistocene fluvial calcareous gravels and sands, about $4.5 \mathrm{~m}$ deep and deposited over Upper Greensand. The gravel layer is covered by 1.2 to $1.4 \mathrm{~m}$ of recent silty clay loams derived from the upper reaches of the catchment and river alluvium, which form the present floodplain surface.

King's Meadow and Queen's Arbour are drained by a ditch parallel to the river, dug in the alluvium, at the foot of the terrace and linked to the river by a perpendicular ditch which separates the two meadows (Fig. 1). The main ditch also drains water seeping from the terrace. Ten years ago, both meadows were ploughed and reseeded with perennial rye grass (Lolium perenne). They were subsequently cut for silage and grazed heavily by cattle, with annual applications of manure and mineral fertiliser (Stevenson et al., 2000). According to the National Vegetation Classification (NVC; Rodwell, 1992), the current vegetation is mainly MG7 Lolium perenne ley, with some stands being close to OV23 Lolium perenne - Dactylis glomerata weedy grass community, OV25 Urtica dioica-Cirsium arvense tall herbs community, and in wetter places, OV28 Agrostis stolonifera - Ranunculus repens muddy grass community.

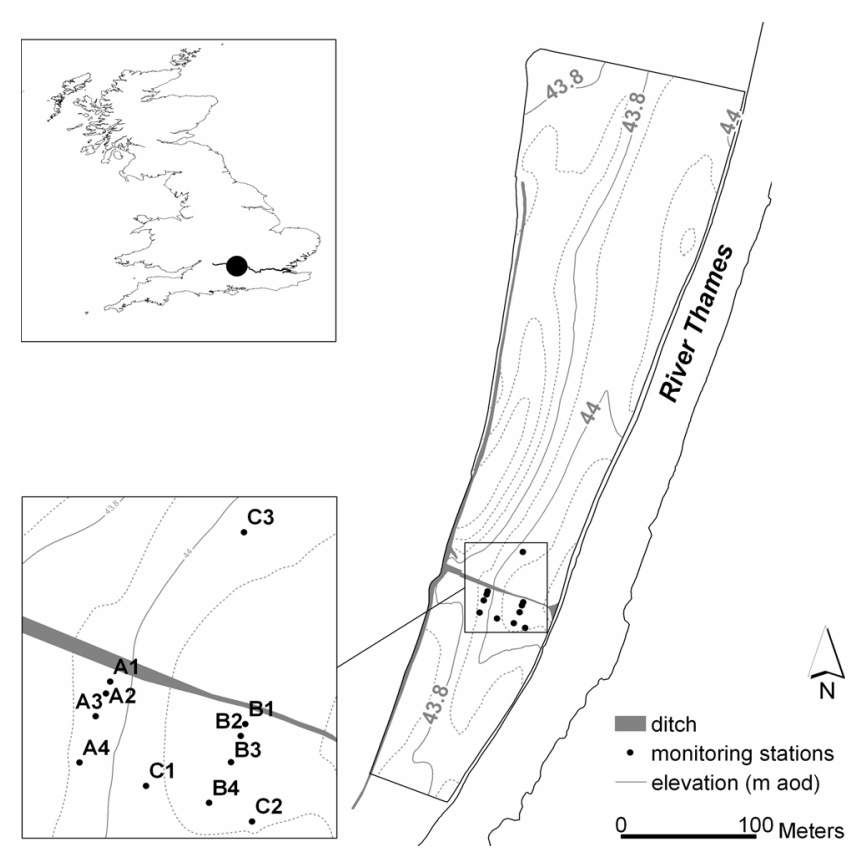

Fig. 1. Castle Meadows and location of the monitoring stations. 
In 1999, Castle Meadows were purchased by South Oxfordshire District Council for restoration and conservation purposes and the management was contracted to the Northmoor Trust. The management plan (Stevenson et al., 2000) planned the restoration of species-rich plant communities characteristic of wet meadows in King's Meadow and Queen's Arbour. The precise conservation objective for wet meadows was defined as the restoration and maintenance of the meadows in favourable condition where "the species composition of the grassland includes locally appropriate grass and forb species of wet grassland (MG6, MG4, MG8), including Cynosurus cristatus (crested dog's tail), Sanguisorba officinalis (great burnet), Prunella vulgaris (self heal), and Saxifraga granulata (meadow saxifrage)" and where "standing water remains on the meadow into March" (Stevenson et al., 2000).

To fulfil this objective, the restoration plan includes two main approaches, alongside the reinstatement of traditional extensive management:

(1) The perpendicular ditch was dammed to raise water levels. It was hoped that this would increase wetness in the adjacent alluvium which would in turn promote wet grassland species and it was envisaged that the elevated and stable water level in the ditch would improve habitat for water voles and otters.

(2) Hay, cut from nearby existing species-rich meadows, was spread to compensate for lack of propagules of the target species.

\section{Method}

\section{HYDROLOGICAL ASSESSMENT}

\section{Groundwater and surface water monitoring}

Eleven hydrological monitoring stations were installed in Queen's Arbour in 2004 (Fig. 1). Each station consists of a dipwell ( $1.5 \mathrm{~m}$ deep) measuring the groundwater table level in the alluvium and a piezometer ( $5 \mathrm{~m}$ deep) measuring the piezometric head in the underlying gravel layer. A stage board was installed in the ditch upstream of the dam and in the river. All instrumentation was levelled to Ordnance Datum. Surface and groundwater level observations were made fortnightly in summer and once a month in winter from February 2004, as part of a core programme aimed at understanding floodplain eco-hydrological processes.

\section{Flooding regime}

A rating curve was developed by comparing known river levels and flow on the same day using a linear regression $\left(y=0.013 x+42.3, n=16, r^{2}=0.99, p<0.001\right)$. Some river level data (10 points) were obtained from the stage board installed at the site. However, since none of these observations corresponded to a flood event, supplementary data were required. These were obtained by pinpointing fixed landmarks at the same level as the water surface on photographs of flooding events and relating them to Ordnance Datum by levelling. Five data points were obtained using this method, taken from photographs by Northmoor Trust staff. Two other river water levels were obtained by direct levelling for the 1999 and 2003 flood maxima. Flow data for the Thames at the nearest gauging station, Days Weir, $5 \mathrm{~km}$ upstream of Wallingford, were provided by the National Water Archive. The relationship between river water level at Castle Meadows and flow at Days Weir was established by regression analysis. This relationship and the flow record for the period 1980-2002 were subsequently used to estimate daily river water levels for the same period.

Figure 2 shows a sample of the data set derived in this way. This method was evaluated using data for 2005 which were not included in derivation of the regression model. A comparison of observed and calculated water levels shows that the regression model estimates high river levels and therefore flood duration and frequency.

A $1 \times 1 \mathrm{~m}$ digital elevation model of the whole site was derived by linear interpolation of a triangular irregular network based on 192 points covering both King's Meadow and Queen's Arbour levelled to Ordnance Datum. The combination of estimated daily river water levels derived using the method described above and this elevation model within ArcView GIS enabled the calculation of flood regime statistics (maximum and cumulative duration of inundation for each season) for each cell of the elevation model. The accuracy of the GIS model was evaluated by comparing computed maps of the extent of 11 distinct flood events with sketches of the extent of surface water drawn in the field (Northmoor Trust, 2003). On average, 84\% of the $1 \times 1 \mathrm{~m}$ cells were assigned correctly by the GIS model to the flooded or non-flooded categories. This was considered acceptable given the relative imprecision of the sketches.

\section{Suitability for NVC communities}

To assess whether the hydrological requirements of speciesrich communities defined as targets for Castle Meadows restoration were met at the site, observed groundwater levels and calculated flood regime characteristics were compared with known requirements of two wet grassland communities of conservation interest, as described in the Ecohydrological Guidelines for Lowland Wetland Plant Communities (Wheeler et al., 2004). These two communities were MG4 and MG8. These guidelines have been derived from long- 


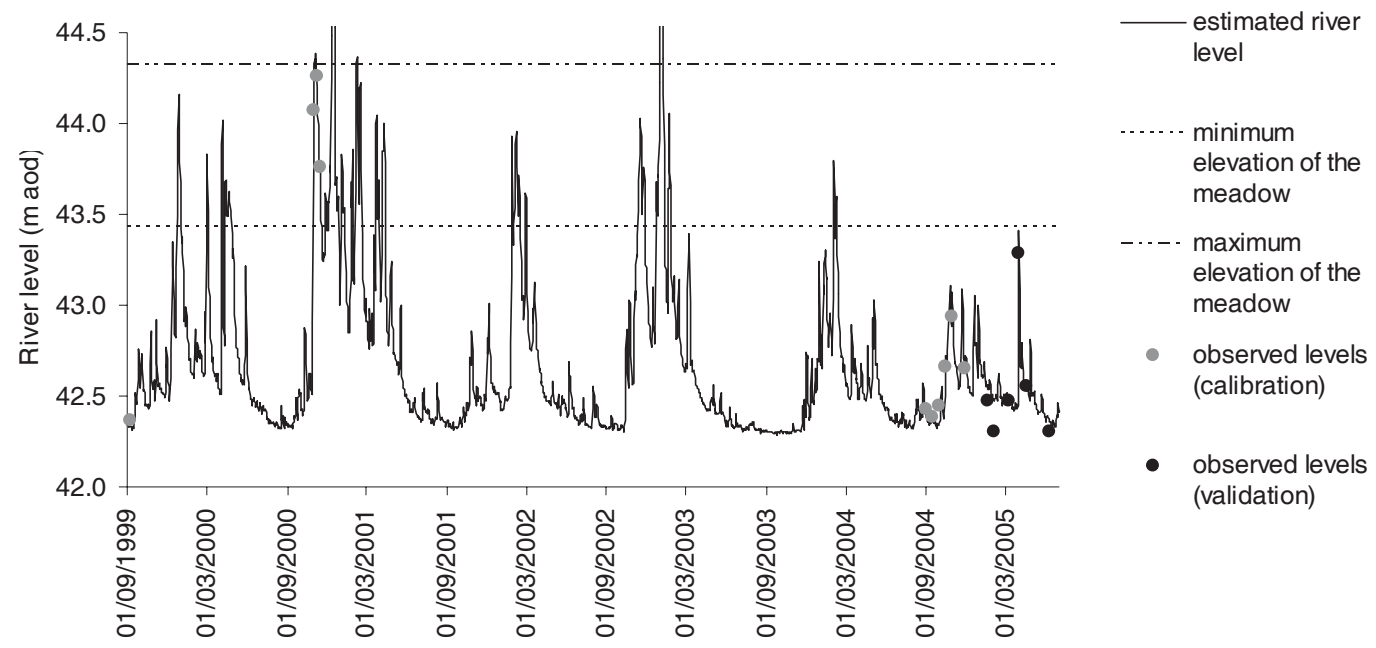

Fig. 2. A sample of the time series of estimated river levels at Castle Meadows.

term hydrological monitoring of wet grasslands in a favourable state of conservation. For both communities and for four variables (the minimum and maximum water table depth, the maximum duration of surface flooding and the cumulative duration of surface flooding for each season), they give a series of values classified as:

- target values (values within which the community usually occurs);

- border values (values which, if experienced in most years, will result in a gradual change in the community);

- unsuitable values (thresholds which, if breached in one year, are likely to lead to a change in the community).

The provision of the digital elevation model for both King's Meadow and Queen's Arbour enabled a comparison of the flooding characteristics with vegetation requirements for the whole site. However, the availability of groundwater data restricted this part of the analysis to Queen's Arbour.

\section{Nutrient status and vegetation characteristics}

To assess whether soil phosphate concentrations would impede the restoration of Castle Meadows into more speciesrich communities, conditions were compared with two reference sites located in the Thames Valley, upstream of Castle Meadows. These two reference sites, at Chimney Meadow National Nature Reserve (grid reference SP352000) and Oxey Meadow Site of Special Scientific Interest (grid reference SU478106), had existing speciesrich semi-natural wet meadows. All three sites have broadly the same geo-physical characteristics but differ in their management history.

At each site, vegetation was described using the phytosociological abundance-dominance method, as implemented in the National Vegetation Classification (NVC; Rodwell, 1992). Vascular plants were recorded in $1 \times 1 \mathrm{~m}$ quadrats $(2 \times 2 \mathrm{~m}$ at Castle Meadows due to the very low species richness), and their coverage estimated using a 1 to 10 scale. Seventy-eight quadrats were surveyed (Castle Meadows: 27, Chimney Meadow: 38, Oxey Meadow: 13) and were classified according to the NVC using Tablefit scores (Hill, 1996).

Soil analysis was performed on two $10 \mathrm{~cm}$ soil cores taken from within each quadrat for all Castle Meadows quadrats and 26 quadrats from Chimney and Oxey Meadows belonging to MG4 Alopecurus pratensis - Sanguisorba officinalis or MG5 Centaurea nigra-Cynosurus cristatus communities. At Chimney Meadow, the cores were taken immediately adjacent to each plot to prevent damage to the vegetation, the plots being part of a long-term monitoring scheme. The samples were frozen until analysis one to two weeks later, which is a common method of preservation (Pezzolesi et al, 2000). After thawing, the two samples taken in the same plot were thoroughly crushed and mixed together. Water content (soil moisture) was determined by weight loss of 15 grams of wet soil after drying at $105^{\circ} \mathrm{C}$ for 12 hours. A 1:100 suspension of dried soil in water was filtered using glass-fibre filters, after shaking vigorously and allowing the suspended particles to settle. Phosphate concentrations in the solution were measured with a DR/ 2010 spectrophotometer, using the PhosVer 3 (ascorbic acid) method (Hach Company, 1999).

Dried samples were kept at $550^{\circ} \mathrm{C}$ in a furnace for two hours. The percentage of mass loss on ignition was used as an approximation for the organic matter content. Soil $\mathrm{pH}$ was measured using an electrical probe in a 1:100 soil 
suspension in water, and nitrate concentrations in the soil solution were measured after reaction with cadmium (Hach Company, 1999). Water-extractable nitrogen and phosphorus were expressed in $\mathrm{mg} \mathrm{g}^{-1}$ of dry soil, correcting for the water content of the corresponding sample. Soil particles were sized by washing through a column of sieves after complete destruction of the organic matter with hydrogen peroxide. This method only allowed for the separation of sand $(2 \mathrm{~mm}-53 \mu \mathrm{m})$, coarse silts $(53-38 \mu \mathrm{m})$ and clay and fine silts $(<38 \mu \mathrm{m})$. For practical purposes the last two fractions are referred to as 'silt' and 'clay'. Differences between sites and NVC groups were investigated using an ANOVA in SPSS 11 after logtransforming soil variables and checking for normality using QQ plots.

\section{Results}

EFFECTS OF ECOLOGICAL FACTORS ON CASTLE MEADOWS VEGETATION

The mean cumulative flooding period in the growing season (March to September) was calculated for each vegetation quadrat at Castle Meadows using the digital elevation model and time series of river water levels previously established.

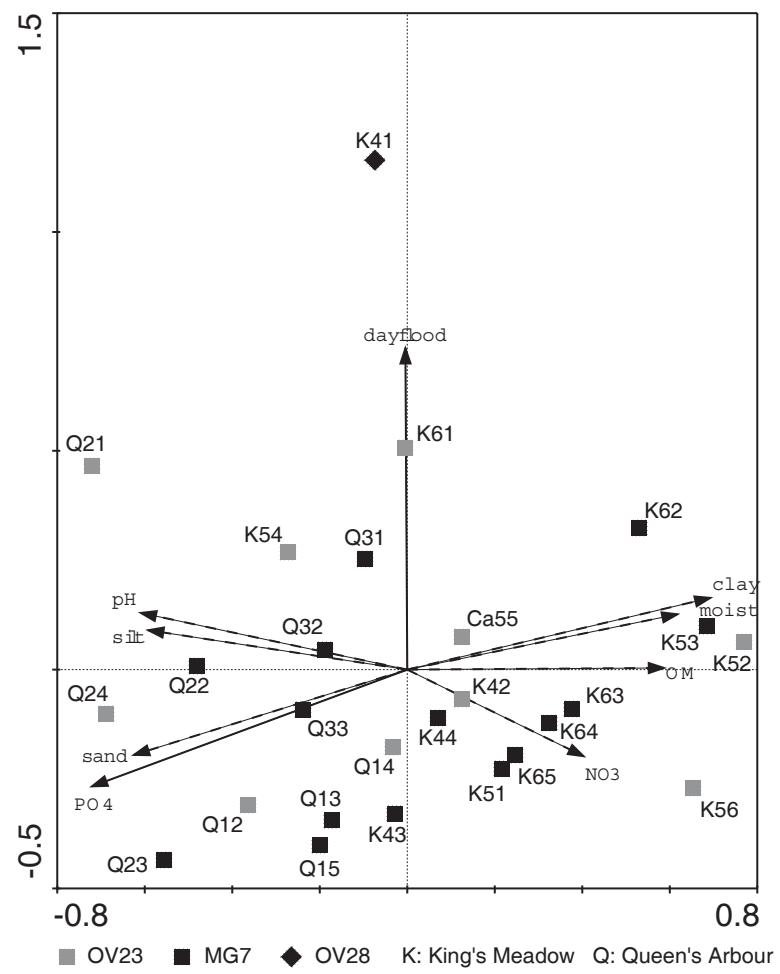

Its effect and the impact of soil variables on vegetation at Castle Meadows were investigated with a Redundancy Analysis (RDA) using Canoco 4.5. Altogether, environmental variables explained $43.8 \%$ of the floristic variation. The first two axes of the RDA accounted for $27.3 \%$ of this variation and $62.3 \%$ of the proportion of the floristic variation explained by the environmental variables.

The ordination graph (Fig. 3) summarises the main characteristics of the vegetation and of its relationship with environmental variables. It shows that the vegetation is organised along two main axes. The first axis distinguished between samples from King's Meadow (K) and from Queen's Arbour (Q). The first group of these quadrats had high coverage of Dactylis glomerata and Phleum pratense, the second group had high coverage of Arrhenatherum elatius, Poa trivialis, Rumex sanguineus and Convolvulus arvensis. This axis was correlated with all soil variables except nitrate ( $\mathrm{r}$ between 0.556 and 0.683 ). The second RDA axis clearly distinguished the sample K41 and, less distinctively, the sample K61 from the rest of the quadrats, on the basis of a high coverage of Alopecurus geniculatus and Agrostis stolonifera and a low coverage of Lolium perenne. This axis was correlated to the mean annual cumulative flooding period in the growing season $(\mathrm{r}=0.781)$. However, when included in a stepwise model to explain the

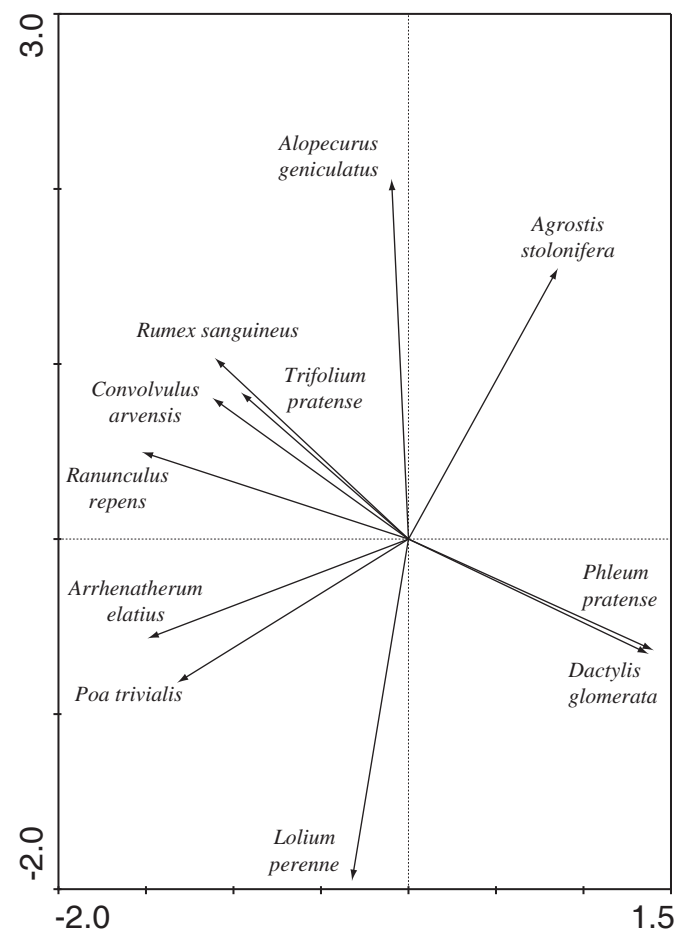

Fig. 3. RDA biplots of Castle Meadows'samples. Left: samples \& soil variables; right: species. Plot scales are not the same. Only environmental variables represented by plain arrows are significant in explaining the floristic axes.

dayflood: mean cumulative flooding period in the growing season; moist: soil moisture; OM: loss on ignition. 
floristic variation, only phosphate (explaining the first axis, $\mathrm{p}=0.002$ ) and the cumulative flooding period (explaining the second axis, $\mathrm{p}=0.007$ ) were significant.

\section{WATER EXTRACTABLE PHOSPHATE LOAD}

There was a clear distinction in water-extractable phosphorus between the sites $(\mathrm{F}=76.244, \mathrm{df}=56, \mathrm{p}<0.0001)$. Semi-natural sites had the lowest concentrations $(2.79 \times$ $\left.10^{-3} \pm 1.62 \times 10^{-3} \mathrm{mg} \mathrm{g}^{-1}\right)$. Phosphorus concentrations were nearly six times higher at Queen's Arbour $\left(1.64 \times 10^{-2} \pm\right.$ $\left.5.76 \times 10^{-3} \mathrm{mg} \mathrm{g}^{-1}\right)$. King's Arbour had an intermediate load $\left(6.89 \times 10^{-3} \pm 2.99 \times 10^{-3} \mathrm{mg} \mathrm{g}^{-1}\right)$.

\section{HYDROLOGY}

\section{Flooding regime}

Figure 4 shows the mean duration of the longest period over which each $1 \times 1 \mathrm{~m}$ cell of the GIS elevation model was flooded in spring, summer, autumn and winter for the period 1985-2004. The comparison of these flooding characteristics with the known requirement of MG4 and MG8 (Wheeler et al., 2004) shows that the maximum duration of floods, especially in autumn and winter, could be a limiting factor for restoration of MG4 and even MG8 in the lowest part of the meadow (Fig. 5). Furthermore, the MG4 result was due not to a single high-magnitude lowfrequency event but was the result of recurring flood events
Spring

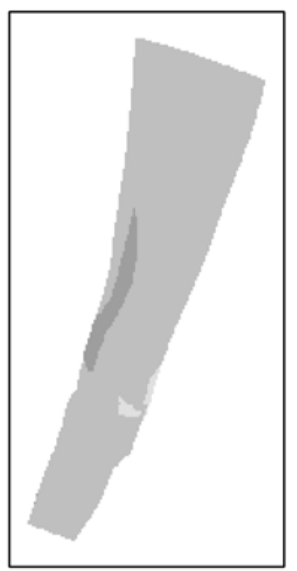

Summer

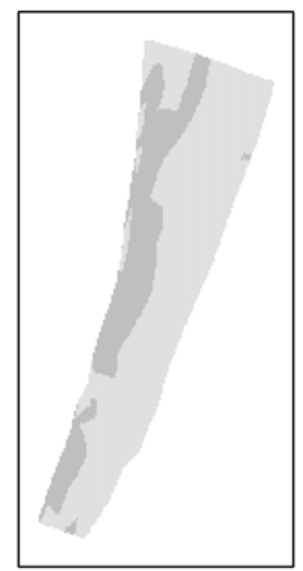

Autumn

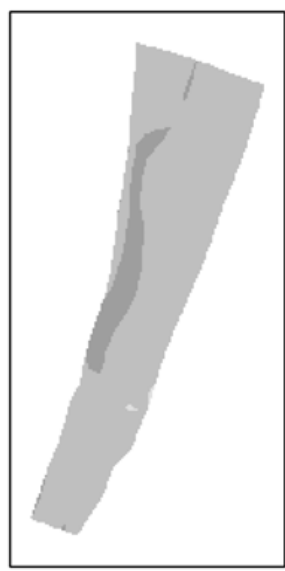

Winter

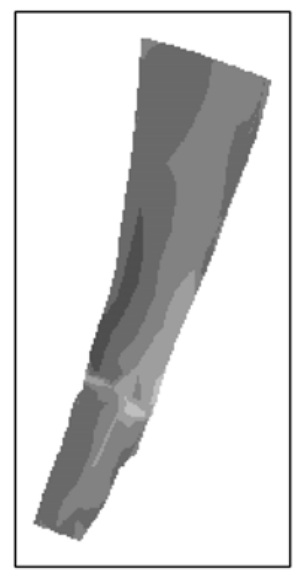

$\square 0 \square 0-2 \square 2-4 \square 4-6 \square 6-10 \square 10-14$

Fig. 4. Mean duration of the longest period of inundation (days): 1985-2004.

Spring

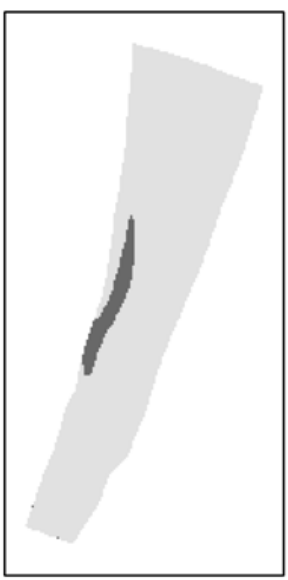

Summer

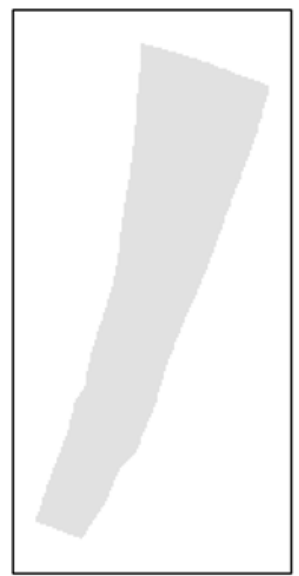

Autumn

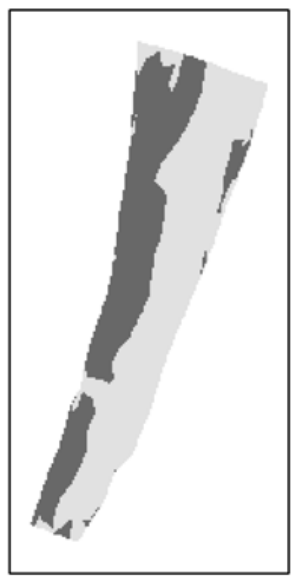

Winter

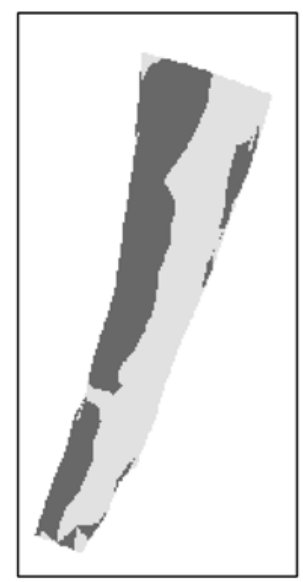

$\square$ suitable

unsuitable (highly detrimental event has occured at least once)

Fig. 5. Suitability for MG4 community re-creation based on inundation duration. 


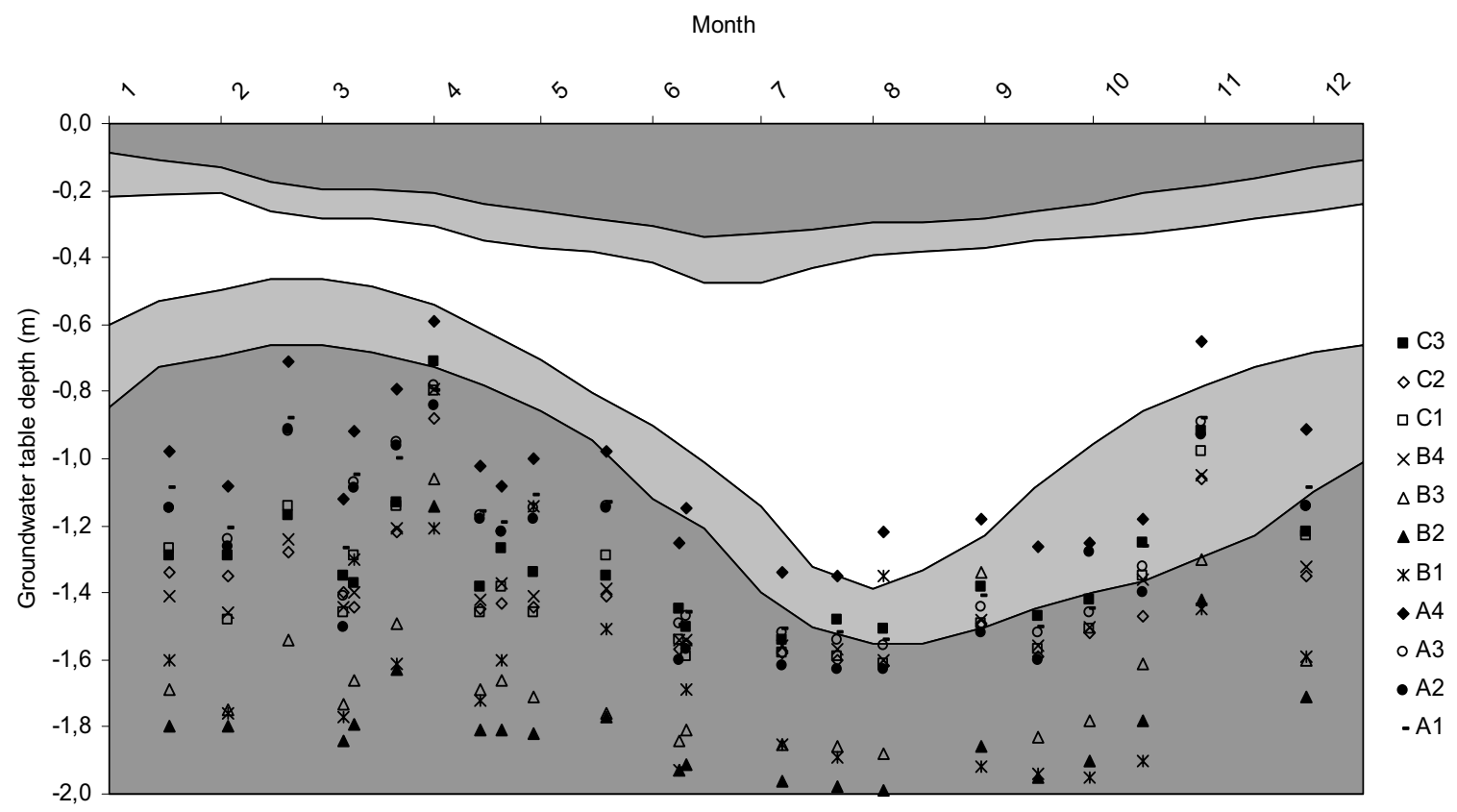

Fig. 6. Groundwater table depths at each monitoring station plotted against ecohydrological guidelines for MG4 wet grassland. White area: target values for the community; light grey area: range of values which, if experienced in most years, will results in a change in the community; dark grey area: range of values which, if experienced in one year only, are likely to result in a change in the community (Wheeler et al., 2004). See Fig. 1 for explanation of dipwells codes.

lasting in the lower part of the meadow for more than 12 days in autumn and 18 days in winter, thresholds suggested as unsuitable for this community.

\section{Groundwater table regime}

Although in the higher part of the meadow the flooding regime does not appear to be a limiting factor for MG4 restoration, the observed groundwater table depths were almost always greater than the maximum depth required for MG4 wet grassland communities (Wheeler et al., 2004; Fig. 6). It is therefore probable that the area for which water table depth data are available is unsuitable for restoration of this species-rich community. Moreover, it should be emphasised that the data on which this assessment is based have been collected after the construction of the dam in the perpendicular ditch which was designed to raise water levels. The same conclusion can be drawn for MG8 which requires even shallower groundwater tables.

\section{Discussion}

Although not directly comparable with other more sophisticated and sensitive methods used in the literature (Critchley et al., 2002; Gowing et al., 2002), waterextractable phosphorus analysis provides a widely accepted (e.g. Hossner and Phillips, 1973), quick and relatively cheap method for assessing whether or not phosphorus is likely to be an obstacle to species-rich meadow restoration. Although the analysis for this project was undertaken in a laboratory, field kits could equally be used for analysing nutrient levels in water in the environment (e.g. James et al., 2005). Indeed, the move to in situ measurements of phosphorus would allow not only rapid survey, but would also overcome potential issues of sample deterioration in storage.

Walker et al. (2004) estimated that published reference values for UK Biodiversity Action Plan priority habitats (Critchley et al., 2002) should be considered with caution since soil variables have marked regional variations. They prefer to compare the site to be restored with a local existing meadow, to assess the extent to which it differs from seminatural grasslands. In such a case, analysis of phosphates in the soil solution is a cost-effective approach for site managers.

Large differences in water-extractable phosphorus between improved grasslands at Castle Meadows and seminatural reference communities at Chimney and Oxey Meadows showed that high phosphate concentrations are likely to be an obstacle for species-rich meadow restoration at Castle Meadows (Marrs, 1993). However, differences between King's Meadow and Queen's Arbour as a whole and between individual samples were reflected by the vegetation. Phosphate was one of the two factors explaining 
the floristic variation in the site. Similarly, in a large-scale fertiliser experiment, Tallowin et al. (1998) showed that phosphorus was more influential than nitrogen or potassium in determining plant composition in wet meadows. Some areas in King's Arbour with the lowest phosphate concentrations may revert to species-rich meadow under the management regime currently applied and seed importation. However, at Queen's Arbour, it is unlikely that targets could be met in the medium term; more drastic restoration operations, such as deep ploughing, cereal cropping if feasible, and seed spreading would be needed. In advance of this, the vertical distribution of phosphorus in the soil should be investigated more thoroughly to ensure that ploughing would succeed in lowering concentrations below the target value proposed by Gough and Marrs (1990a, b).

A contributory factor in the high levels of phosphorus in the soil may have been the very elevated phosphorus concentrations in Thames river water. The Thames river catchment is essentially agricultural with inputs of nutrients from both point sources (urban discharges at sewage treatment works (STWs) for market towns such as Banbury, Oxford and Aylesbury) as well as diffuse (agricultural) sources. Until 1999, mean soluble reactive phosphorus (SRP) concentrations in the Thames adjacent to the Meadows were $255 \mu \mathrm{g} \mathrm{l}^{-1}$ during winter high flows with maximum levels of $2121 \mu \mathrm{g} \mathrm{l^{-1 }}$ during summer low flows (Neal et al., 2000); the upper limit proposed under the Water Framework Directive is $100 \mu \mathrm{g} \mathrm{l^{-1 }}$. The mean concentration of particulate phosphorus, deposited on the floodplain with fine sediments, was $125 \mathrm{\mu g}^{-1}$ during winter high flows (Neal et al., 2000). Phosphate stripping, introduced to STWs in the upper Thames during 1999, reduced phosphorus levels by around 50\% (Fig. 7; Neal et al., 2005). While SRP concentrations decreased significantly following phosphorus removal from STWs, there was no corresponding reduction in particulate $\mathrm{P}$ because the SRP reduced only at the STWs, while within-sediment stores of $P$ will be long lasting in the river. Nevertheless, the relatively high residual concentrations of phosphorus in the Thames, compared to more natural rivers in the same area - such as the River Pang, where SPR concentrations range from 7 to $134 \mu \mathrm{g} \mathrm{l}^{-1}$ (Neal et al., 2004) - imposes a further constraint on reducing soil phosphorus levels in the Castle Meadows floodplain.

The GIS approach to estimating flooding characteristics assumed that there were no obstacles to water movement from/to the river. Since depressions in Castle Meadows were almost entirely drained by the ditch, this assumption was realistic before the dam was constructed. The hydrological analysis suggests that before construction of the dam MG4

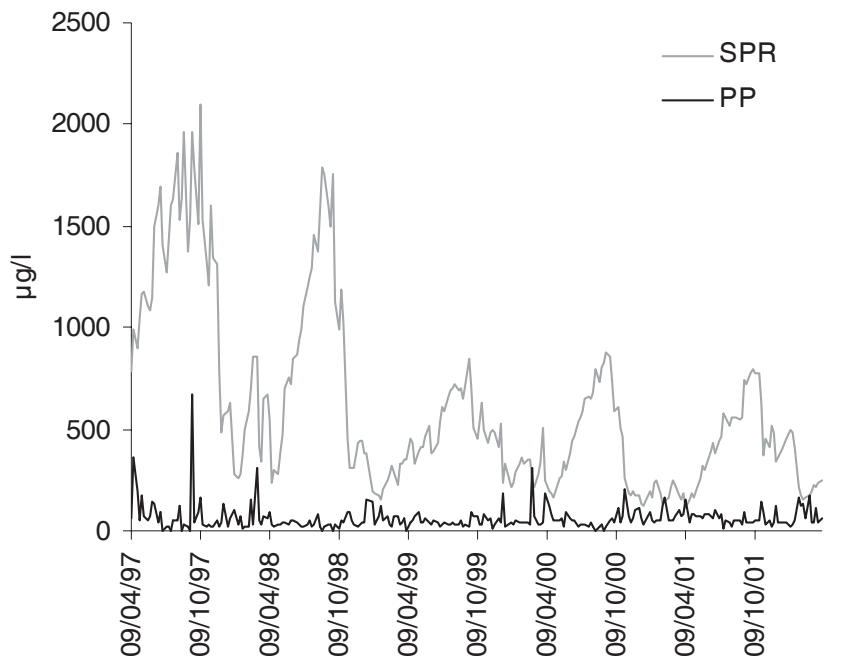

Fig. 7. Soluble reactive phosphorus (SPR) and particulate phosphorus (PP) concentrations in the River Thames adjacent to the Castle Meadows (Neal et al., 2005).

restoration at Castle Meadows would have been limited by the excessive duration of floods in the lower part of the meadow. The dam has increased the maximum duration of flooding events by retaining water which would otherwise have drained to the river. This has further reduced the suitability of the lower part of the meadow for MG4 and MG8 wet grasslands communities. This conclusion is consistent with the floristic composition of the quadrat K41. Characterised by Agrostis stolonifera and Alopecurus geniculatus, classified as OV28, it also shows a floristic proximity with MG13. This last community would be a more appropriate target for this part of the meadow.

Gowing et al. (2002) highlighted the susceptibility of MG4 meadows to excessive waterlogging. They are a man-made community, developed in situations with efficient drainage systems. Excess water is a more acute threat for this community than soil drying. Existing drainage systems are often thought to be an obstacle to species-rich wet meadow restoration. Dams in ditches are seen as a way to enhance nature conservation interest through rewetting. The pertinence of rewetting should however be carefully assessed against conservation targets (Swetnam et al., 1998). Dam construction without control of ditch water levels may result in overbank inundation and excessive waterlogging through water retention after flood events, especially on slowly draining soils. The effects of dams on vegetation will be different if water levels in ditches are controlled and used to sustain the groundwater table without over-topping banks.

The Castle Meadows study highlights the importance of defining restoration targets on the basis of a sound 
understanding of site hydrology. In a review of information sources used by British conservationists, Pullin et al. (2004) showed that nature reserve management plans and day-today management decisions were based mainly on the continuation of traditional practices and on informal advice from colleagues or experts. In the context of floodplain species-rich meadow restoration, this type of information may well lead to establishment of unsuitable targets.

For site managers considering floodplain meadow restoration, a simple model, based on easily available data such as river flow and topographic survey combined with water level requirements of target communities such as those provided by Wheeler et al. (2004) would be a relatively easy step toward the evidence-based framework advocated by Pullin et al. (2004) for conservation decisions. It would provide a means of dismissing communities which are not suitable targets due to excessive waterlogging. Analysis of the groundwater table, especially during the growing season, is the next stage of site assessment. At Castle Meadows the limiting factor for MG4 restoration on higher ground is not the duration of floods but the low level of the groundwater table, which has not been raised sufficiently by the construction of the dam in the ditch draining the site. In this case, MG5 Cynosurus cristatus - Centaurea nigra meadow is likely to be a more achievable target, provided the phosphorus concentration is low enough, as in some stands in King's Meadow, or is lowered by appropriate management.

\section{Conclusion}

The UK Biodiversity Action Plan and similar initiatives across Europe have triggered a great demand for lowland meadow restoration. Although restoration has been proved to be possible (Walker et al., 2004), constraints are numerous. These are linked to both the physical and biological environment. Water level regime and nutrient loads are the two main physical factors influencing vegetation and therefore restoration success. The first step in restoration needs to be an assessment of hydrological and hydro-chemical regimes of the site to determine its potential to support species-rich grassland. A full analysis is complex and beyond the budget and expertise of many conservation organisations. A straightforward technique, applicable in the field without the need for detailed laboratory analysis, has been demonstrated in a case study on the River Thames floodplain in the UK. It has shown that low summer water table levels, long flood inundation in the winter and high phosphate concentrations in the soil water render the site unsuitable for the MG4 plant community; that establishment of MG5 or MG13 grasslands, depending on topography, may be more achievable conservation targets. This test shows that the technique could be readily applied to other wet grassland restoration sites.

\section{Aknowledgements}

The authors are grateful to the following people for their collaboration in this study: Jane Fisher, Manuel Angel Dueñas, Owen Mountford, Colin Neal, Richard Williams (Centre for Ecology and Hydrology, Wallingford); Janet Hope, Ian Patmore and Tula Maxted (Physical Geography Laboratory, UCL); Olivia Breffit and Steve Gregory (Northmoor Trust); Dominic Lamb (South Oxfordshire District Council); Kerry Lock (Berkshire, Buckinghamshire and Oxon Wildlife Trust). A. Duranel acknowledges the financial support of the British Council through an 'Entente Cordiale' scholarship for his MSc in Conservation, Department of Geography, UCL.

\section{References}

Acreman, M. and José, P.J., 2000. Wetlands. In: Hydrology of the UK, a study of change, M. Acreman (Ed.), Routledge, Chichester, UK. 88-102.

Bischoff, A., 2002. Dispersal and establishment of floodplain grassland species as limiting factors in restoration. Biol. Conserv., 104, 25-33.

Critchley, C.N.R., Chambers, B.J., Fowbert, J.A., Sanderson, R.A., Bhogal, A. and Rose, S.C., 2002. Association between lowland grassland plant communities and soil properties. Biol. Conserv., 105, 199-215.

Donath, T.W., Holzel, N. and Otte, A., 2003. The impact of site conditions and seed dispersal on restoration success in alluvial meadows. Appl. Veg. Sci., 6, 13-22.

Gilbert, J.C., Gowing, D.J.G. and Bullock, R.J., 2003. Influence of seed mixture and hydrological regime on the establishment of a diverse grassland sward at a site with high phosphorus availability. Restor. Ecol., 11, 424-435.

Gough, M.W. and Marrs, R.H., 1990a. A comparison of soil fertility between semi-natural and agricultural plant-communities implications for the creation of species-rich grassland on abandoned agricultural land. Biol. Conserv., 51, 83-96.

Gough, M.W. and Marrs, R.H., 1990b. Trends in soil chemistry and floristics associated with the establishment of a low-input meadow system on an arable clay soil in Essex, England. Biol. Conserv., 52, 135-146.

Gowing, D.J.G. and Youngs, E.G., 1997. The effect of the hydrology of a Thames flood meadow on its vegetation pattern. In: Proc. British Hydrological Society National Meeting, 5th June 1996, Birmingham, UK, R.G. Large, (Ed.), British Hydrological Society, London, UK. 69-80.

Gowing, D.J.G. and Spoor, G., 1998. The effect of water table depth on the distribution of plant species on lowland wet grassland. In: United Kingdom floodplains, R.G. Bailey, P.V. José, and B.R. Sherwood, (Eds.), Westbury Academic and Scientific Publishing, Otley, UK. 185-196.

Gowing, D.J.G., Tallowin, J.R.B., Dise, N.B., Goodyear, J., Dodd, M.E. and Lodge, R.J., 2002. A review of the ecology, hydrology and nutrient dynamics of floodplain meadows in England. English Nature Research Report $n^{\circ} 446$, English Nature, Peterborough, UK. 
Grevilliot, F., Krebs, L. and Muller, S., 1998. Comparative importance and interference of hydrological conditions and soil nutrient gradients in floristic biodiversity in flood meadows. Biodivers. Conserv., 7, 1495-1520.

Hach Company, 1999. DR/2010 spectrophotometer procedures manual. Hach Company, Loveland State, USA.

Hill, M.O., 1996. TABLEFIT version 1.0, for identification of vegetation types. Institute of Terrestrial Ecology, Huntingdon, UK.

Hossner, L.R. and Phillips, D.P., 1973. Extraction of soil solution from flooded soil using a porous plastic filter. Soil Sci. 115, $87-88$.

James, C., Fisher, J., Russel, V., Collings, S. and Moss, B., 2005. Nitrate availability and hydrophyte species richness in shallow lakes. Freshwater Biol. 50, 1049-1063.

Janssens, F., Peeters, A., Tallowin, J.R.B., Bakker, J.P., Bekker, R.M., Fillat, F. and Oomes, M.J.M., 1998. Relationship between soil chemical factors and grassland diversity. Plant Soil, 202, 69-78.

Manchester, S.J., Mountford, J.O., Treweek, J.R. and Sparks, T.H., 1998a. Experimental reconstruction and rehabilitation of floodplain grasslands. In: United Kingdom floodplains. Westbury Publishing, Westbury, UK. 379-394.

Manchester, S.J., Treweek, J.R., Mountford, J.O., Pywell, R.F. and Sparks, T.H., 1998b. Restoration of a target wet grassland community on ex-arable land. In: European wet grasslands: biodiversity, management and restoration, C.B. Joyce and P. Max Wade (Eds.), Wiley, Chichester, England, UK. 278-294.

Manchester, S.J., McNally, S., Treweek, J.R., Sparks, T.H. and Mountford, J.O., 1999. The cost and practicality of techniques for the reversion of arable land to lowland wet grassland - an experimental study and review. J. Environ. Manage., 55, 91109.

Marrs, R.H., 1993. Soil fertility and nature conservation in Europe - theoretical considerations and practical management solutions. Adv. Ecol. Res., 24, 241--300.

McDonald, A.W., 2001. Succession during the re-creation of a flood-meadow 1985-1999. Appl. Veg. Sci., 4, 167-176.

Neal, C., Williams, R.J., Neal, M., Bhardwaj, L.C., Wickham, H., Harrow, M. and Hill, L.K., 2000. The water quality of the River Thames at a rural site downstream of Oxford. Sci. Total Envir., 251, 441-457.

Neal, C., Skeffington, R., Neal, M., Wyatt, R., Wickham, H., Hill, L. and Hewitt, N., 2004. Rainfall and runoff water quality of the Pang and Lambourn, tributaries of the River Thames, southeastern England. Hydrol. Earth Syst. Sci., 8, 601-613.

Neal, C., Jarvie, H.P., Neal, M., Love, A.J., Hill, L. and Wickham, H., 2005. Water quality of treated sewage effluent in a rural area of the upper Thames Basin, southern England, and the impacts of such effluents on riverine phosphorus concentrations. J. Hydrol., 304, 103-117.
Northmoor Trust, 2003. Flood levels for 2003 at Castle Meadows. Northmoor Trust, Little Wittenham, Oxon, UK.

Oomes, M.J.M., Olff, H. and Altena, H.J., 1996. Effects of vegetation management and raising the water table on nutrient dynamics and vegetation change in a wet grassland. J. Appl. Ecol., 33, 576-588.

Pezzolesi, T.P., Zartman, R.E. and Hickey, M.G., 2000. Effects of storage methods on chemical values of water logged soils. Wetlands, 20, 189-193.

Pullin, A.S., Knight, T.M., Stone, D.A. and Charman, K., 2004. Do conservation managers use scientific evidence to support their decision-making? Biol. Conserv., 119, 245-252.

Pywell, R.F., Bullock, J.M., Hopkins, A., Walker, K.J., Sparks, T.H., Burke, M.J.W. and Peel, S., 2002. Restoration of speciesrich grassland on arable land: assessing the limiting processes using a multi-site experiment. J. Appl. Ecol., 39, 294-309.

Rodwell, J.S. (Ed.), 1992. British plant communities. Volume 3. Grasslands and montane communities. Cambridge University Press, Cambridge, UK.

Snow, C.S.R., Marrs, R.H. and Merrick, L., 1997. Trends in soil chemistry and floristics associated with the establishment of a low-input meadow system on an arable clay soil in Essex. Biol. Conserv., 79, 35-41.

Stevenson, M., Coulson, S., Gregory, S. and Head, S., 2000. Wallingford Castle Meadows and the remains of Wallingford Castle - Site management plan April 2000 - April 2005. Northmoor Trust, Little Wittenham,Oxon, UK.

Swetnam, R.D., Mountford, J.O., Armstrong, A.C., Gowing, D.J.G., Brown, N.J., Manchester, S.J. and Treweek, J.R., 1998. Spatial relationships between site hydrology and the occurrence of grassland of conservation importance: a risk assessment with GIS. J. Environ. Manage., 54, 189-203.

Tallowin, J.R.B., Kirkham, F.W., Smith, R. and Mountford, J.O., 1998. Residual effects of phosphorus fertilization on the restoration of floristic diversity to wet grassland. In: European wet grasslands: biodiversity, management and restoration, C.B. Joyce and P. Max Wade (Eds.), Wiley, Chichester, UK. 249263.

UK Steering Group, 1995. Biodiversity: The UK Steering Group report - Volume I: Meeting the Rio challenge. HMSO, London.

Walker, K.J., Stevens, P.A., Stevens, D.P., Mountford, J.O., Manchester, S.J. and Pywell, R.F., 2004. The restoration and re-creation of species-rich lowland grassland on land formerly managed for intensive agriculture in the UK. Biol. Conserv., 119, $1-18$.

Wheeler, B.D., Gowing, D.J.G., Shaw, S.C., Mountford, J.O. and Money, R.P., 2004. Ecohydrological guidelines for lowland wetland plant communities. Environment Agency (Anglian Region), Peterborough, UK. 